\title{
Fatty Acid-Binding Protein, Liver
}

National Cancer Institute

\section{Source}

National Cancer Institute. Fatty Acid-Binding Protein, Liver. NCI Thesaurus. Code C29615.

Fatty acid-binding protein, liver (127 aa, $14 \mathrm{kDa}$ ) is encoded by the human FABP1 gene.

This protein is involved in binding to bilirubin, and fatty acids and their acetyl coenzyme A derivatives. 